\title{
Immigration, Freedom, and the History of the Institute for Advanced Study
}

\author{
Fadi Bardawil', Thomas Dodman', Ian Jauslin³, Pascal Marichalar 4 \\ Klaus Oschema ${ }^{5}$, and Peter Redfield ${ }^{6}$
}

\author{
Communicated by Harriet Pollatsek
}

In response to the January 27, 2017, US presidential executive order initially banning travel and immigration from seven predominantly Muslim countries, members of the Institute for Advanced Study (IAS) mobilized a History Working Group. This article is adapted from their reports in the spring 2017 IAS Newsletter. The full articles, as well as a companion exhibit showcasing original materials from the Institute's archives, are also available on the IAS website $^{7}$ and in print/ebook as a booklet.

\footnotetext{
${ }_{1}^{1}$ Fadi Bardawil is an anthropologist at the University of North Carolina at Chapel Hill, and a former Member (2016-2017) of the School of Social Science at the IAS. His e-mail address is bardawi 1 @ emai 1 . unc. edu

${ }^{2}$ Thomas Dodman is a historian at Columbia University, and a former Member (2016-2017) of the School of Historical Studies at the IAS. His e-mail address is td2551@columbia. edu

${ }^{3}$ Ian Jauslin is a Member (2016-2017) of the School of Mathematics at the IAS. His e-mail address is jaus1 in@ias.edu

${ }^{4}$ Pascal Marichalar is a sociologist and historian with the French $\mathrm{Na-}$ tional Center for Scientific Research (CNRS), and a former Member (2016-2017) of the School of Social Science, IAS. His e-mail address is pascal.marichalar@cnrs.fr

${ }^{5}$ Klaus Oschema is a historian at the Ruhr-Universität Bochum, and a former Member (2016-2017) of the School of Historical Studies at the IAS. His e-mail address is $\mathrm{k} 1$ aus.oschema@ruhr-universitaet-bochum. de

${ }^{6}$ Peter Redfield is an anthropologist at the University of North Carolina at Chapel Hill, and a former Member (2016-2017) of the School of Social Science at the IAS. His e-mail address is redfield@unc. edu
}

7 www.ias.edu/idea-tags/history-working-group

For permission to reprint this article, please contact:

reprint-permission@ams .org.

DOI: http://dx.doi.org/10.1090/noti1596

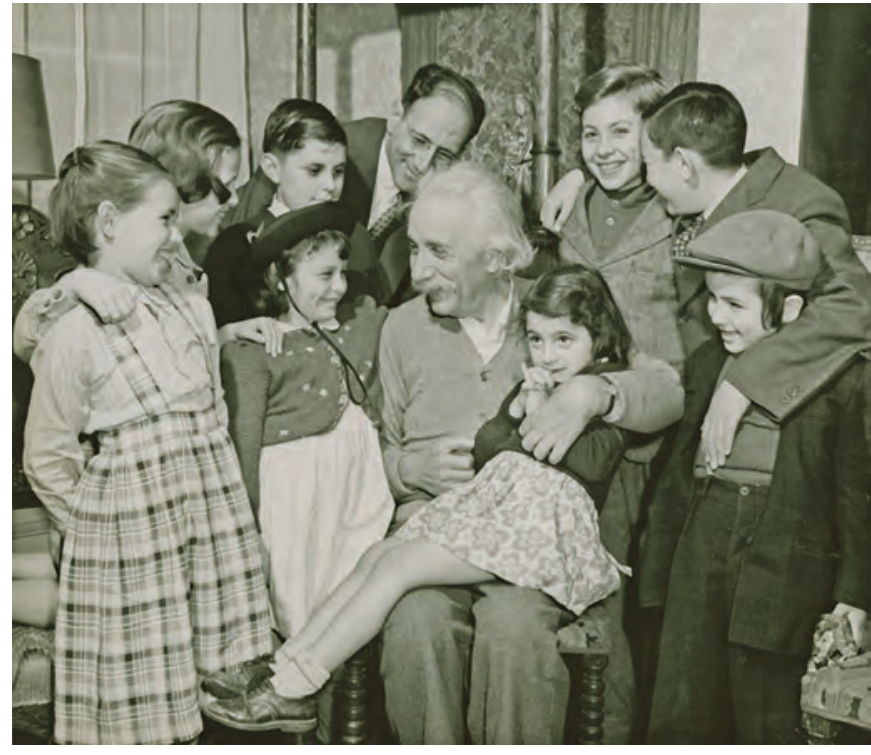

Figure 1: Albert Einstein at his home, 112 Mercer Street in Princeton, New Jersey, with a group of World War II European Jewish refugee children.

\section{The Institute's Founding Ethos in Our Precarious Present}

The Institute for Advanced Study came into being at the most inauspicious of times. Founded in the early years of the Great Depression, it took shape during the buildup to the Second World War and under the growing shadow of authoritarian regimes. Its first director, Abraham Flexner, published his manifesto on "The Usefulness of Useless Knowledge" in October 1939, barely a month after the outbreak of hostilities in Europe. Surely this was a daunting moment to defend "the fearless and irresponsible thinker" 
and advocate for the free expression of knowledge and curiosity.

The very adversity of the era, however, created opportunities for the fledgling institution, primarily in the form of sudden availability of renowned and newly mobile scholars from the upper echelons of the German university system. After expressing initial hesitation, Flexner followed the urging of influential faculty members, particularly the mathematician Oswald Veblen, in seeking to provide a haven for some of these new refugees, a sanctuary tradition continued by Frank Aydelotte, Flexner's successor. In association with the Emergency Committee in Aid of Displaced Foreign Scholars, the Rockefeller Foundation, and the Carnegie Foundation, the IAS played a leading role in this farsighted, if ever elite, rescue effort.

We find ourselves today, nearly nine decades after the Institute's founding in 1930, at another inauspicious juncture. Global political forces in power from Turkey to the United States are posing serious threats to the autonomy of scientific research and the mobility of researchers, undercutting two cardinal conditions for scientific progress. Walls, fences, bans, blocks, restrictions, cuts, and expulsions are slowly becoming run-of-the-mill terms for us to navigate in an increasingly precarious political landscape.

Travel restrictions involving pure accidents of birth, documented by passports from flagged countries, have prompted us to revisit today the Institute's history. We seek to provide sketches of earlier scholarly lives and scientific cultures interrupted by nationalist forces of exclusion. That these lives and cultures managed to reconstitute themselves and enrich our common human heritage is thanks to efforts to provide them with sanctuary.

\section{The Conversion of Abraham Flexner}

At the end of January 1933, Adolf Hitler became chancellor of Germany. Over the next two months, the Nazi Party moved quickly to consolidate its power, expanding executive authority through emergency decrees and swiftly moving into a formal dictatorship. An edict in April initiated a purge of civil servants who were of non-Aryan descent or exhibited suspect political sentiments. This law directly impacted German universities, and it had a particularly strong effect in the fields of mathematics and natural sciences, where Jews had enjoyed better prospects of pursuing a scholarly career. As a consequence, many of the country's strongest intellectual centers lost leading figures in the space of just a few months, including the renowned Mathematical Institute at the University of Göttingen, home of David Hilbert, Richard Courant, Hermann Weyl, and Emmy Noether. This upheaval produced a sudden wave of refugee scholars seeking to emigrate and desperate to find positions elsewhere. It also coincided with the transition of IAS from a concept to an embodied institution, through the founding of the inaugural School of Mathematics.

The crisis of refugee scholars presented Flexner and Veblen with a challenging opportunity. The Institute had already pulled an extraordinary coup in recruiting Albert Einstein and John von Neumann shortly before Hitler's coming to power. But how far should they continue in recruiting additional émigrés? Flexner initially expressed ambivalence on the topic, torn between a desire to live up to founding ideals and concern over the need to support and foster local talent. He wrote to Veblen on March 27, 1933: "Mr. Bamberger and Mrs. Fuld were very anxious from the outset that no distinction should be made as respects race, religion, nationality, etc., and of course I am in thorough sympathy with their point of view, but on the other hand if we do not develop America, who is going to do it, and the question arises how much we ought to do for others and how much to make sure that civilization in America advances." On May 2, again responding to Veblen, he expanded on the same theme: "We are certainly in the devil of a fix. Unable to care for our own younger men, we are pressed by applications from foreign countries. It seems to me clear that we must in the first place endeavor to find work for those whom we have encouraged to train themselves in this country on the theory that, if they were worthy, there would be jobs waiting for them. Until we have done that, what else can we do? Our opportunities for making places for foreigners are therefore at the moment limited to a few outstanding personages such as Einstein and Weyl ...."

For his part, Veblen pressed for a more active stance, not only advocating that the Institute do all it could, but also endorsing the establishment of a formal network to provide assistance to scholars in need. He wrote to Flexner on May 5: "Some kind of a committee to raise funds for the purpose of enabling some of them to live and continue their scholarly work in the countries adjacent to Germany or elsewhere might be feasible. The existence of such a committee would in itself be an eloquent protest." That same month, the Institute of International Education in New York City set up its Emergency Committee in Aid of Displaced German Scholars (later renamed to include all Foreign Scholars), headed by Edward R. Murrow, to assist scholars fleeing Europe. Veblen would join its board soon thereafter.

Over the course of the ensuing years, Flexner would undergo a conversion, becoming more deeply involved in assistance projects-he followed Veblen into the Emergency Committee-and increasingly willing to mobilize the Institute to this effect. In a 1938 letter to George Birkhoff at Harvard, he insisted that national origin should never stand in the way of higher goals: "Let us keep firmly in front of our eyes our real goal, namely the development of mathematics, not American mathematics or any other specific brand of mathematics, just simply mathematics. It can be developed only by having first-rate men in important posts, and every time an institution gets one first-rate man he creates opportunities for other first-rate men, and every such center that is developed stimulates some other institution to do likewise. Hitler has played into our hands and is still doing it like the mad man that he is. I am sorry for Germany. I am glad for the United States. I will undertake to get a position within a reasonable time for any really first-rate American mathematician, and I will also undertake simultaneously to do the same for any 
first-rate foreign mathematician whom Hitler may dismiss. The more the merrier."

In his director's report the following spring, Flexner even cast the matter as heralding a seismic change in the geography of knowledge: "We are living in an epoch-making time. The center of human culture is being shifted under our very eyes. Once it had its home in Athens. A few centuries later it had its home in Italy, a few centuries later in Paris, and thereafter also in Great Britain and Germany. It is now being unmistakably shifted to the United States. The scholars of Europe are refugees driven out of their own countries sometimes for political or religious reasons and sometimes because they are too unhappy and too distracted to pursue the work to which they are giving their lives. They have come to the Institute or have corresponded with the Institute literally by the hundreds. We cannot, of course, undertake either to give them places or to find them places, though we have done something substantial under both heads. Fifty years from now the historian looking backward will, if we act with courage and imagination, report that during our time the center of gravity in scholarship moved across the Atlantic Ocean to the United States. It is a grave responsibility which is thus being thrust upon us all." From a vantage point almost eighty years later, Flexner's claim seems more prophetic than hyperbolic. Although the transference in scientific work away from German and toward global English may have begun earlier, the center of gravity clearly shifted in the second half of the twentieth century. Germany's leading share of Nobel Prizes plummeted after the war, even as the number of American laureates soared (one third of whom were foreign born).

\section{"A wall of bureaucratic measures"}

The actual process of reaching the United States was far from simple for most would-be immigrants, who had to navigate not just an ocean, but also a maze of paperwork to obtain the requisite permission to exit and enter. To assist them, Flexner and Aydelotte used their extensive contacts and pulled strings as much as possible. When the mathematical logician Kurt Gödel found himself unable to leave Vienna in October 1939, Flexner contacted the chief of the visa division at the Department of State to plead on his behalf. Although Gödel had been legally admitted as a permanent resident earlier in the 1930s, he had returned to the annexed country that used to be Austria, and was facing difficulty getting authorization to return to the United States. "Is there anything that the State Department or the Consul General can do," Flexner asked, "to suggest some helpful method of procedure?" The American authorities answered that the problem seemed to be with German authorities, and so Flexner's successor Aydelotte contacted the German embassy in Washington. Eventually Gödel and his wife Adele were permitted to leave. By German directive they traveled east instead of west, avoiding
British surveillance of the Atlantic by crossing Siberia and eventually getting to Japan in 1940, where they found a boat to San Francisco. In a letter thanking Aydelotte (Figure 2), Gödel mentioned, "I am told in all steamship bureaux that the danger for German citizens to be arrested by the English is very great on the Atlantic."

Even after refugees succeeded in reaching the United States, they needed to stay bureaucratically alert, and often required assistance. Under the Alien Registration Act of 1940, the US Immigration and Naturalization Service collected fingerprints and required noncitizens to record all changes of address (see Figure 3). Even local travel could necessitate permission, such that Gödel, once finally settled in Princeton, had to request permission to travel with his wife to visit a doctor in New York City in January 1942. They always went by train, Gödel assured the US Attorney, and returned on the same day. Three weeks later, Aydelotte's secretary sent a follow-up plea, noting, "If you could grant them this permission promptly it would be a great relief to them and would be very much appreciated."

The Institute's most famous scholar in exile, Albert Einstein, underscored the unending hassles that hindered attempts to welcome foreign scholars in a letter he wrote

$$
\begin{aligned}
& \text { Vimmar Jan. 5, } 1940 \\
& \text { Dear D Agole (The } \\
& \text { I am greatly obeiged to yow for the request, which you } \\
& \text { have addrenced on my behalf to the Germain chargé } \\
& \text { ol' Affoines in Washingtow. IT is probably on this account } \\
& \text { Thut I was ultimatey yranted leave by the Germoin } \\
& \text { unthrities. In viev of Plop. Veflens Cethe of Dec. } 1 \\
& \text { I un hoping mor, that it will make no difficulty } \\
& \text { to obtaim the Amaiarn vise and that } J \text { shall be able } \\
& \text { to leave Viomse in a fer dags. So the only compliation } \\
& \text { which remains is, that I shall have to Take the route } \\
& \text { though Russin and Japan. The Germain certificate of } \\
& \text { lever makes explicitly this reguinemant and in adolition } \\
& \text { I om told in all STeamsip. buscanx, that the danyer } \\
& \text { in Germain citizens to be anested by the English } \\
& \text { is very greut on the ATlantic. } \\
& \text { I ugnet very much, that the tip over Jupan }
\end{aligned}
$$

Figure 2: Letter from Kurt Gödel to IAS Director Frank Aydelotte, January 5, 1940, expressing gratitude for his and Flexner's help in securing permission for the Gödels to leave Vienna. 


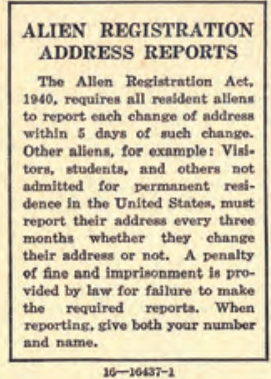

DEPARTMENT OF JUSTICE, IMMIGRATION AND NATURALIZATION SERVICE, ALIEN REGISTRATION DIVISION, PHILADELPHIA, PA.

Figure 3: Under the Alien Registration Act of 1940, noncitizens were required to record all changes of address, and even local travel could necessitate permission.

to Eleanor Roosevelt on July 26, 1941: "A policy is now being pursued in the State Department which makes it all but impossible to give refuge in America to many worthy persons who are the victims of Fascist cruelty in Europe. Of course, this is not openly avowed by those responsible for it. The method which is being used, however, is to make immigration impossible by erecting a wall of bureaucratic measures alleged to be necessary to protect America against subversive, dangerous elements."

\section{A Call for Vigilance}

As we immersed ourselves in the thicket of correspondence at the heart of the Institute's archives, the sense of urgency expressed by scholars like Flexner, Veblen, Aydelotte, Einstein, and Noether resonated deeply. Their notes and exchanges, not to mention the Emergency Committee in Aid for Displaced Foreign Scholars that Flexner and Veblen served on, had an unsettling contemporary ring to them. This part of courage to provide sanctuary for displaced refugees the Institute's history testifies to the individual courage of these men and women who extended a helping hand and built institutional networks to provide sanctuary for displaced refugees. In doing so, they overcame the nationalist siege-mentality that sees foreigners, whether they are mathematicians or fruit pickers, as a threat to be warded off. An unintended consequence of their acts was the shifting of the center of intellectual research from Germany to the United States, enriching the country that gave them refuge. Their individual initiatives and collective institution-building endeavors provide us with much-needed exemplars of moral fortitude.

There is a darker side to this story. It only took a few months and one edict purging civil servants of nonAryan descent or exhibiting suspect political sentiments in April 1933 to drain the German university of many of its brightest minds and its intellectual vigor. Of course, the contemporary political situation in the United States remains far from this extreme case. Nonetheless, knowledge of this history should serve as a call for vigilance in the face of policies such as travel bans and immigrant deportations, as well as attempts to curb scientific inquiry and cut funding to arts and humanities endowments that now threaten the autonomy of research and the pursuit of a dignified human life. Unfortunately, history suggests it takes much less time to destroy than to build. As it did in the 1930s, the Institute can play a leading symbolic role in our contemporary predicament.

\section{Emmy Noether}

To Einstein, she was "the most significant creative mathematical genius thus far produced since the higher education of women began." More straightforward in his praise, Einstein's fellow professor at the Institute for Advanced Study, Weyl, called her a "great woman mathematician [...indeed] the greatest that history has known." It was April 1935, and Einstein and Weyl were each paying tribute to a recently deceased colleague who had, like them, fled Nazi persecution across the Atlantic only two years earlier. Her name was Emmy Noether, and her short but remarkable life left an indelible
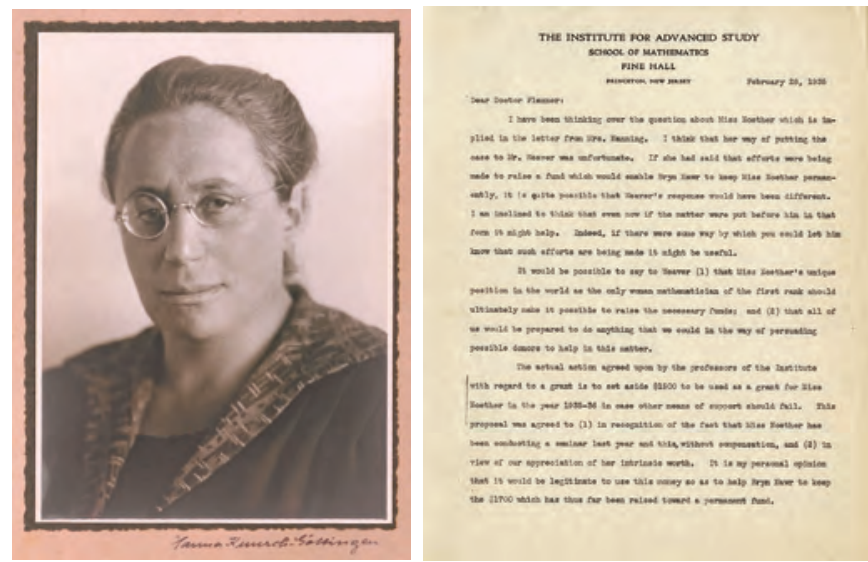

Figure 4: Left: Mathematician Emmy Noether, who had been forced to flee Göttingen, began giving weekly lectures at IAS as a Visitor in the School of Mathematics. Right: Letter from Oswald Veblen to Abraham Flexner, dated February 28, 1935, regarding a $\$ 1,500$ grant for Noether.

mark not only on the history of mathematics, but also on that of IAS in its critical first years.

Amalie Emmy Noether was born in 1882 into an affluent family from the Bavarian town of Erlangen. She followed her father's footsteps to study mathematics at the University of Erlangen and, in 1907, she became the second woman to obtain a PhD in mathematics from a German university. A female maverick in a man's world, Noether taught for several years without pay before being invited, in 1915, to join the University of Göttingen, home to the most prestigious mathematics department in the world at 
the time. She lectured for other professors and was only allowed to pass her habilitation following the collapse of the Kaiserreich and sweeping university reforms in 1919. Noether became an adjunct professor in 1922-the first female professor in Germany-but only started receiving a modest compensation for her teaching the following year.

Despite international recognition, she never obtained a permanent position in Göttingen, and her situation took a turn for the worst with the rise to power of the Nazi party. In 1932, she was denounced by a neighbor as a "Marxist Jewess" and had to leave her apartment. The following year, she was removed from all teaching duties at the university and was eventually forced to flee Germany like many other purged academics. (See Figure 4, left.) Thanks to the intervention of the Emergency Committee in Aid of Displaced German Scholars, Noether was able to take a temporary position at Bryn Mawr College. Once in Pennsylvania, she reconnected with her former Göttingen colleague Weyl, himself freshly recruited to the Institute for Advanced Study by its first director, Flexner, and resident professors Veblen and Einstein.

It was during her years in Göttingen that Emmy Noether developed an international reputation as a formidable mathematician. She made seminal contributions to the field of abstract algebra, where she identified a simple, yet elegant, property of number systems, which proved instrumental in the study of arithmetic and geometric phenomena such as prime decomposition and dimension. (See the sidebar on Emmy Noether's contributions to algebra.)

Noether brought similar clarity to her pioneering research in physics, where she understood the relationship between symmetries of the laws of nature and the notion of "conservation laws." As an illustration, consider the "principle of energy conservation," a paradigmatic conservation law, which states that the total energy of an isolated system cannot change. When a car accelerates, for instance, its energy increases, implying that it must have drawn energy from somewhere, according to the principle of energy conservation (in this case, from burning gasoline). On the other hand, consider "time-translation invariance," a fundamental symmetry of the laws of nature, which states that an experiment performed today would give the same outcome if performed tomorrow: the speed of a free-falling cannonball is the same now as it was in the time of Galileo. Noether was able to connect these two seemingly unrelated concepts: energy conservation comes from time-translation invariance and vice versa. Scientists had long known the connection between energy and time, but Noether was the first to theorize a systematic correspondence: symmetries and conservation laws are related, in general. The idea arose out of a debate between David Hilbert, Felix Klein, and Einstein over the notion of energy in Einstein's recently formulated general theory of relativity. Noether's theorem not only laid this controversy to rest, but, due to its striking generality, has been widely used in many other fields of physics, perhaps most notably in the study of elementary particles.

\section{Rethinking the Scholar's Paradise in the 1930s}

Emmy Noether was thus already a household name among mathematicians when Veblen approached Flexner about supporting her in the United States. Their personal correspondence reveals how the Institute was forced to reconsider its mission in the face of unprecedented assaults on scholars in Europe. Noether's position at Bryn Mawr was funded by the Rockefeller Foundation (as part of their $\$ 1.5$ million aid package for displaced scholars) but was only temporary. At Veblen's invitation, she began giving weekly lectures at the Institute as a visitor in the School of Mathematics, where she joined the first cohort of IAS Members. Noether was happy to be at the Institute-and not at Princeton's "men's university, where nothing female is admitted," as she once said-but she didn't receive any honorariums for her lectures, unlike seventeen other occasional visiting lecturers, all male, who spoke at the Institute throughout the 1930s. On the other hand, Veblen did request a small grant-in-aid, to help keep her at Bryn Mawr through 1935 and 1936, on the grounds of "Miss Noether's unique position in the world as the only woman mathematician of the first rank." Flexner was sympathetic to Noether's plight, but worried about the Institute overcommitting, and he repeatedly encouraged Veblen to view the question as an administrator. Flexner wondered what such a short-term commitment could achieve and expressed concern at the Institute doing any more than what it already had for German scholars, as it needed to be "careful not to create the impression that [it was] overlooking Americans in order to help these unfortunate foreigners." Sidestepping the thorny issue of nationality, Veblen was eventually able to secure a $\$ 1,500$ grant and continued soliciting larger donations for a "permanent commitment on the part of the Institute." (See Figure 4, right.) As he put it, Noether was not merely unique as a "woman mathematician," she offered the Institute an opportunity to capitalize on the brain-drain from Göttingen by supporting "one of the most important scientists" displaced by the events in Germany.

Assisting endangered scholars presented, in other words, as many opportunities as it entailed risks and burdens for the newly established IAS. Flexner himself came around to seeing this, albeit only after Noether's untimely death on April 14, 1935. No doubt inspired by Weyl's and Einstein's stirring obituaries, he invoked her memory in a lecture on "The Usefulness of Useless Knowledge"-an idea he had long pursued and would, two years later, publish as his famous article in Harper's magazine-that he gave at Bryn Mawr on June 2, 1937. Noether, he had come to believe, "was driven from Göttingen for no better reason than that she was a Jewess." Bryn Mawr had "welcomed her with open arms," as many other institutions had done for other scholars at risk across the country. "This is civilization," Flexner concluded, "this is culture... . a country like America, of which only a small fraction has been culturally developed, can only be enriched by the folly which drives great thinkers, novelists, dramatists, and poets out of the Old World to make a fresh start in the New." Flexner's words ring loud today, as a reminder of how the Institute 


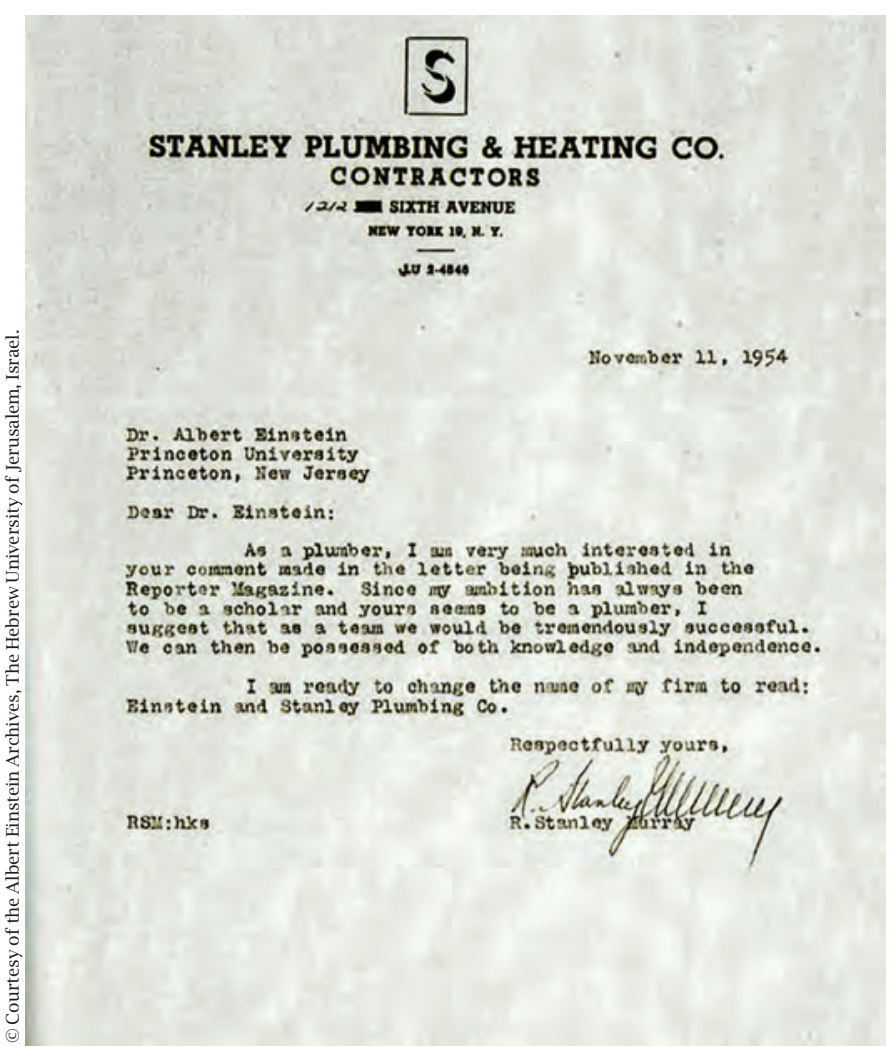

Figure 5: Stanley Murray, a New York City plumber, responded to Albert Einstein's professed interest in being a plumber.

found a new raison d'être in challenging times, and as an admonition of how fragile and contingent "scholars' paradises" such as the IAS, or Göttingen before it, can be.

\section{Einstein, Plumbers, and McCarthyism}

In November 1954, Einstein wrote a letter to a magazine in which he declared that, were he a young man again, he would not try to become a scientist: "I would rather choose to be a plumber or a peddler in the hope to find that modest degree of independence still available under present circumstances." Around the United States, plumbers responded. The famous physicist was offered membership in the Chicago plumbers union, and Stanley Murray, a New York plumber, wrote to him (Figure 5): "Since my ambition has always been to be a scholar and yours seems to be a plumber, I suggest that as a team we would be tremendously successful. We can then be possessed by both knowledge and independence. I am ready to change the name of my firm to read: Einstein and Stanley Plumbing Co.”

Einstein was only half joking, however, when he issued his statement. The physicist sincerely considered that the political climate in the country was becoming increasingly hostile to scientists and teachers. Our own troubled times have many aspects in common with the dreadful period of the McCarthy investigations: the attacks on the freedom of academics, teachers, and the press, the silencing and censorship of government workers, the idea that the
United States is threatened by certain creeds. It is worth describing the dire sequence of past events, and learning from Einstein's clairvoyant and courageous response to them, in order to best address the present situation.

On February 9, 1950, Senator Joseph McCarthy from Wisconsin announced that he had a list of 205 workers of the State Department who were members of the Communist Party. The next day, a journalist asked to see the list. But McCarthy could not find it; his explanation was that he had left it in another suit. The Senate committee that was created to investigate these claims concluded a few months later that McCarthy's accusations represented "perhaps the most nefarious campaign of half-truths and untruth in the history of this republic." Historians are now sure there never was such a list.

Nevertheless, at the time, mainstream Republicans ignored the findings of the Senate committee. They saw McCarthy's tactics as something that would help them take control of the White House, after a sixteen-year absence. They invited him to meetings where he ranted about the "plot" at the highest levels of government. McCarthy's staff also circulated a doctored photograph, purportedly showing the leader of the Senate committee in close conversation with leaders of the Communist Party.

The 1952 elections were a great success for the Republicans, who gained control of the White House, the House of Representatives, and the Senate. Senator McCarthy's power was unchecked. During a speech on the Senate floor, he piled hundreds of documents on a table, claiming they contained evidence of the infiltration. No one was permitted to examine them. McCarthy was nominated chair of the Permanent Subcommittee on Investigations, and he extended the loyalty inquisition to many sectors, foremost among them, the nation's educational system. As a former president of the University of Chicago noted, "The entire teaching profession of the US is now intimidated."

William Frauenglass, a teacher in a Brooklyn high school, was called before the Senate subcommittee in April 1953. In his case, the accusation of disloyalty stemmed from a course he had given six years before, in a session for other teachers organized by the Board of Education. It was called Techniques of Intercultural Teaching, and it reviewed methods to "help ease intercultural or interracial tensions" in the classroom. One witness called upon by the committee declared that such teachings were "against the interests of the United States." Frauenglass was shocked: "Imagine such an accusation when one of the fundamental objectives of public education is the creation of intercultural understanding among our many minorities!" he wrote in a later letter. The teacher was also asked which organizations he belonged to, and he refused to answer.

Frauenglass needed help and decided to ask it from someone he greatly respected, who had recently described himself as an "incorrigible nonconformist": Albert Einstein, Professor of Theoretical Physics at the Institute for Advanced Study in Princeton, undoubtedly the most famous scientist in the world, and also a notorious antiracist and antiwar activist. "A statement from you would be most helpful in rallying educators and the public to 
meet this new obscurantist attack," Frauenglass wrote. Einstein obliged. His May 16, 1953, letter of reply-which, he specified, "need not be considered confidential"-was quoted extensively by The New York Times:

The reactionary politicians have managed to instill suspicion of all intellectual efforts into the public by dangling before their eyes a danger from without. Having succeeded so far, they are now proceeding to suppress the freedom of teaching and to deprive of their positions all those who do not prove submissive, i.e., to starve them.

Einstein strongly advised the teacher to refuse to testify any longer. He should be prepared, Einstein wrote, "for the sacrifice of his personal welfare in the interest of the cultural welfare of his country." The physicist added, "This kind of inquisition violates the spirit of the Constitution. If enough people are ready to take this grave step, they will be successful. If not, then the intellectuals of this country deserve nothing better than the slavery which is intended for them." When Frauenglass and Einstein met in Princeton a few days later, Einstein said he himself was ready to go to jail for these principles. Frauenglass followed his advice. As was foreseen, he was fired from his job, but nevertheless thanked the scientist for a "historic letter": "Its echoes are still reverberating throughout the world."

McCarthy was quick to react to Einstein's stand. He told the media that whether his "name is Einstein or John Jones," the giver of such advice was undoubtedly an "enemy of America," "a disloyal American," and "not a good American." But Einstein was in no way deterred. In remarks he made to an assembly of lawyers, he continued to criticize practices "which have "the right to become incomprehensible to publish and teach what
one holds to
be true"
-Einstein the rest of civilized mankind and exposed our country to ridicule." And he warned, "the existence and validity of human rights are not written in the stars."

Einstein was concerned about the curtailing of academic freedom. In a public statement in March 1954, he advocated for "the right to search for truth and to publish and teach what one holds to be true." He regretted that in this dark age "freedom of teaching, mutual exchange of opinions, and freedom of press and other media of communication are encroached upon or obstructed," adding that "this is a state of affairs which a democratic government cannot survive in the long run."

For some, these statements were proof of Einstein's disloyalty and continued foreignness-he the German Jew who had been granted American citizenship in 1940. In March 1954, a woman from Los Angeles wrote to the Director of the Institute for Advanced Study: "The man needs lessons in Americanism. I have no patience with this idea that a person who has performed a great deed or discovered something, should be excused from what citizens of U.S.A. must conform to, or that they need not account for questionable acts of theirs." A man from New York City put it more bluntly: "I suggest he move to Russia-and soon! We don't need him."

The Director of the Institute at the time, Robert Oppenheimer, himself a target of McCarthy's inquisition, remained steadfast in his support of his famous colleague. Six months later, in December 1954, McCarthy was finally "condemned" by a large majority of his Senate colleagues for "contemptuous" and "reprehensible" conduct. Of course, Einstein's actions did not by themselves cause McCarthy's downfall. But they certainly facilitated it, by reaffirming essential principles that date back to the Enlightenment, and by empowering many others to keep up the continuing fight to protect democracy.

\section{Image Credits}

Figure 1 courtesy of HIAS archive.

Figure 2 Director's Office, Faculty Files, Box 13. "Kurt Gödel." From the Shelby White and Leon Levy Archives Center, Institute for Advanced Study, Princeton, NJ, USA.

Figure 3 Director's Office, General Files, Box 67. "U.S. Immigration and Naturalization Service to 1955." From the Shelby White and Leon Levy Archives Center, Institute for Advanced Study, Princeton, NJ, USA.

Figure 4 (right): Director's Office, Faculty Files, Box 32. "Oswald Veblen." From the Shelby White and Leon Levy Archives Center, Institute for Advanced Study, Princeton, NJ, USA.

Figure 4 (left): Photographic portrait of Emmy Noether, Photo Archives, Special Collections Department, Bryn Mawr College Library.

Figure 5 digital image photographed by Mr. Ardon Bar Hama. Photo of Fadi Bardawil by Børre Ludvigsen.

Photo of Thomas Dodman courtesy of Thomas Dodman. Photo of Ian Jauslin courtesy of Ian Jauslin.

Photo of Pascal Marichalar courtesy of Pascal Marichalar. Photo of Klaus Oschema courtesy of Klaus Oschema. Photo of Peter Redfield by Zoë Tomášková Redfield. 


\section{Emmy Noether's Contributions to Algebra}

From the brochure ${ }^{8}$ for the annual Noether Lectures:

Known primarily for her profound and beautiful theorems in ring theory, Emmy Noether's most significant achievement runs deeper: she changed the way mathematicians think about their subject. "She taught us to think in simple, and thus general, terms... homomorphic image, the group or ring with operators, the ideal... and not in complicated algebraic calculations," said her colleague P. S. Alexandroff during a memorial service after her death. In this way, she cleared a path toward the discovery of new algebraic patterns that had previously been obscured.

\section{From the obituary by B. L. van der Waerden: ${ }^{9}$}

Through her study of the arithmetical theory of algebraic functions, Emmy Noether became familiar with Dedekind's theory of modules and ideals. In her 1920 paper (with Schmeidler), she developed and used concepts from the theory of modules: direct sums and intersections, residue class modules, and isomorphisms of modules. These ideas appear like a red thread throughout her later work.

The first major success of her methods was achieved in 1921 in the classic paper "Idealtheorie in Ringbereichen." Following definitions of the terms "ring" and "ideal," she shows that a finiteness condition (the ascending chain condition) is equivalent to Hilbert's theorem of the finite ideal basis.

Her work forms the immovable foundation of today's "general theory of ideals" and has spawned a long series of highly productive efforts.

The module-theoretic concepts from which she had developed her commutative theory of ideals proved their strength in a non-commutative context as well. Emmy Noether established the close connections among the theories of representation, of modules, and of ideals-first in her lectures in 1924 and then clarified and generalized in her lectures of 1927-1928 and in the resulting paper.

\footnotetext{
${ }^{8}$ The Emmy Noether Lectures, About Emmy Noether (2005), written by Allyn Jackson. www. awm-math.org/noetherbrochure/ AboutNoether.htm 1

${ }^{9}$ Excerpted and paraphrased from B. L. van der Waerden's obituary, published in Mathematische Annalen in 1935 and reprinted in Auguste Dicke's Emmy Noether 1882-1935, transl. H. I. Blocher, Birkhauser Boston (1981) pp. 100-106.
}

EDITOR'S NOTE. See also the following related Notices articles:

Noether's Legacy: Rings in Geometry, by Karen Smith (Jan. 2016) www.ams .org/notices/201601/rnoti-p7.pdf

Mathematicians Fleeing from Nazi Germany: Review of the book by the same title by Reinhard Siegmund-Schultze; Reviewed by Michèle Audin (Nov. 2010) www. ams . org/notices/201010/rtx101001300p.pdf

Emmy Noether: The Mother of Modern Algebra: Review of the book by the same title by M.B.W. Tent; Reviewed by Benno Artmann (Oct. 2009) WWW.ams.org/notices/200909/rtx090901105p.pdf

In Puris Naturabilus: Review of the book "Pursuit of Genius: Flexner, Einstein, and the Early Faculty at the Institute for Advanced Study" by Steve Batterson; Reviewed by Lewis Pyenson (Aug. 2008) www. ams . org/ notices/200807/tx080700793p.pdf

The Vision, Insight, and Influence of Oswald Veblen, by Steve Batterson (May 2007) www.ams.org/notices/200705/fea-batterson-web.pdf

The IAS School of Mathematics at 75, by Susan Friedlander and Mark Goresky (Sept. 2005)www. ams .org/ notices/200508/comm-ias.pdf

The IAS School of Mathematics, by Allyn Jackson (Sept. 2002) www . ams .org/notices/200208/fea-ias .pdf 


\section{COMMUNICATION}

\section{ABOUT THE AUTHORS}

Fadi Bardawil investigates the traditions of intellectual inquiry, practices of public criticism, and modalities of political engagement of contemporary Arab intellectuals, both at home and in the diaspora. In doing so, he tracks the international circulation of theoretical discourses. His current project examines the high tides and ebbing away of leftist revolutionary thought and practice in the Levant.

Thomas Dodman is writing a microhistory of a young soldier and his adoptive family in the age of the French Revolution (1790s-1820s). His study draws on a unique collection of letters and diaries to explore the diffusion of Enlightenment ideas, the impact of war, and a family's emotional life through an era of unprecedented social and political transformation.

Ian Jauslin's research focuses on the mathematical aspects of statistical mechanics and solid state physics. In particular, he is interested in phase transitions in classical and quantum many-particle systems, and in rigorous implementations of the renormalization group.

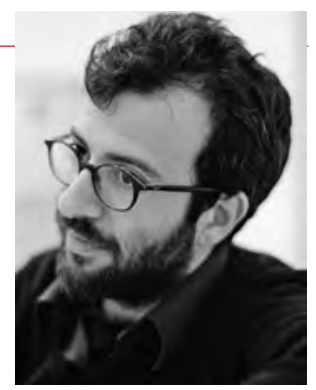

Fadi Bardawil

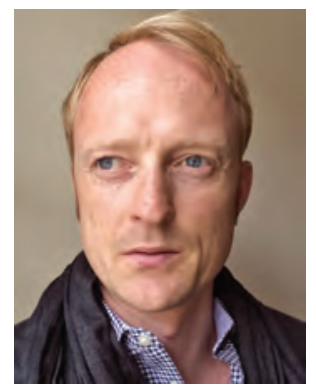

Thomas Dodman

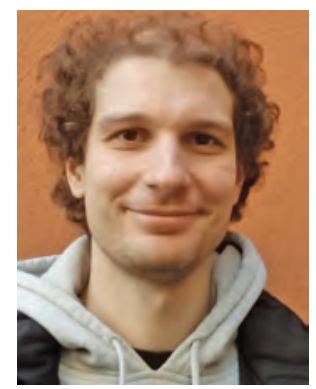

Ian Jauslin
Pascal Marichalar's work is in sociology and history. His research focuses on work, health, pollution and justice.

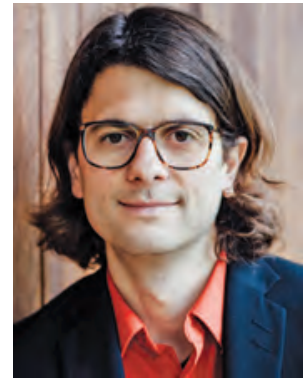

Pascal Marichalar

Klaus Oschema works on astrologers as "experts" in late medieval Europe. He analyzes the mechanisms and strategies, including the aspect of performance, which allowed astrologers to position themselves as experts and to occupy a central role in a variety of contexts of political and social decision-making.

Peter Redfield is exploring humanitarian design and efforts to create innovative devices in response to disaster and poverty globally. His research focuses on conceptions of human needs and ethical responsibilities. He is interested in the politics of technology, particularly questions of scale and accountability beyond state-administered infrastructure.

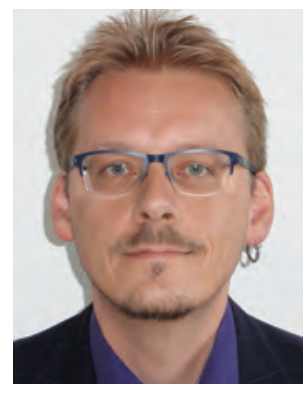

Klaus Oschema

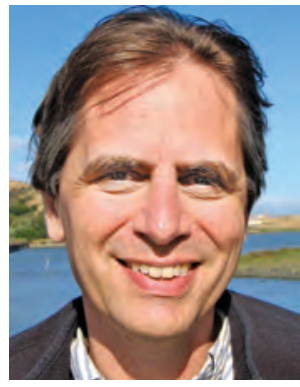

Peter Redfield 